\title{
ОСОБЛИВОСТІ КОНТРОЛІНГУ В СУЧАСНИХ УМОВАХ ГОСПОДАРЮВАННЯ
}

\author{
ОСОБЕННОСТИ КОНТРОЛЛИНГА В СОВРЕМЕННЫХ УСЛОВИЯХ \\ ХОЗЯЙСТВОВАНИЯ
}

\section{CONTROLLING FEATURES IN THE MODERN BUSINESS ENVIRONMENT}

Досліджено теоретичні підходи до трактування сутності економічної категорії «контролінг», визначено концептуальні відмінності щуоо тлумачення зазначеної категорії відповідно до теорій різних економічних шкіл. Визначено тенденції щзодо зміни тлумачення категорії контролінгу залежно від впливу факторів функціонування ринкового середовища в межах певної країни. На основі проведеного дослідження еволюиї сутнісного визначення категорії контролінгу окреслено його принщипові складові та виділено особливості сучасної теорії контролінгу. На основі аналізу фактичних даних виробничих підприємств України визначено проблеми впровадження та функціональні особливості кониепиіі контролінгу з врахуванням загроз макроекономічної нестабільності в краӥні та активізації інтеграційних процесів. Запропоновано методичні підходи до розробки та впровадження системи контролінгу на українських виробничих підприємствах з врахуванням динамічної зміни факторів навколишнього середовища та потенційних загроз сталого розвитку підприємства.

Ключові слова: Контролінг, сталий розвиток, макроекономічна нестабільність, прибуток, управління підприємством, управлінський облік.

Исследованы теоретические подходы $к$ трактовке сущности экономической категории «контроллинг», вылелены концептуальные различия в толковании указанной категории в соответствии с теориями существующих экономических школ. Определены тенденции изменения толкования категории контроллинг в зависимости от влияния факторов функиионирования рыночной среды в пределах определенной страны. На основе проведенного исследования эволюиии сущностного определения категории контроллинга очерчены его принщипиальные составляющие и выделены особенности современной теории контроллинга. На основе анализа фактических данных производственных предприятий Украины определень проблемы внедрения и функииональные особенности концепции контроллина с учетом угроз макроэкономической нестабильности в стране и активизачии интеграчионных прочессов. Предложень методические подходы к разработке и внедрению системы контроллинга на украинских производственных предприятиях с учетом динамического изменения факторов окружающей среды $u$ потенцииальных угроз устойчивого развития предприятия.

Ключевые слова: Контроллинг, устойчивое развитие, макроэкономическая нестабильность, прибыль, управление предприятием, управленческий учет.

Theoretical approaches to the interpretation of the essence of the economic category of "controlling", marked conceptual differences in the interpretation of this category in accordance with 
the existing economic theories schools. Identified trends in the interpretation of the category depending on the controlling factors influence the functioning of the market environment within a particular country. Based on the study of the evolution of the essential definition of the category of controlling outlined its fundamental components and isolated features of the modern theory of controlling. Based on the analysis of evidence of industrial enterprises of Ukraine identified problems of implementation and functional features of the controlling concept with the threat of macroeconomic instability in the country and strengthen the integration process. Methodical approaches to the development and implementation of a controlling system in the Ukrainian industrial enterprises, taking into account the dynamic changes in environmental factors and potential threats to the sustainable development of the enterprise.

Keywords: Controlling, sustainable development, macroeconomic instability, profit, business management, management accounting.

Вступ. Визначення соціальних i економічних цілей підприємства переводить стратегічне бачення i напрям його розвитку на вирішення конкретних завдань, пов'язаних 3 виробництвом продукту i результатами діяльності фірми. Вміння застосувати необхідний інструмент для оптимізації фінансового результату через максимізацію прибутку i цінності капіталу підприємства при гарантованій ліквідності є основною умовою для виживання підприємства в ринковій економіці. Концепція контролінгу визначається як сукупність економічних цілей, завдань, інструментів, суб'єктів і організаційних структур підприємства. Контролінг також можна інтерпретувати як інформаційне забезпечення орієнтованих на результат процесів планування, регулювання і контролю (моніторингу) витрат на підприємстві. Дослідженням проблематики контролінгу, управлінського обліку та в цілому управління підприємством присвячені роботи таких науковців, як Ананькіна О. О. [2], Дайле А. [1], Данілочкіна Н. Г. [2], Манн Р., Майєр С. [4], Пушкар М. С. [5], Фольмут Х. Й. [7], Хан Д. [8], Хорнгрен Ч. [9] та ін. Завдяки роботам науковців було розкрито та досліджено значна кількість теоретичних підходів, що стали основою для грунтовного розуміння сутності контролінгу та його ролі в управлінні підприємством. У дослідженнях, очолюваних вищезазначеними спеціалістами було визначено особливості оперативного та стратегічного контролінгу, проблеми його впровадження на діючих підприємствах, тенденції зміни пріоритетних завдань, що стоять перед менеджерами підприємства тощо. Проте вважаємо, що залишаються недостатньо дослідженим та у певних моментах протиречним питання визначення сутності контролінгу 3 врахуванням сучасних умов господарювання, макроекономічної нестабільності та глобальних інтеграційних процесів у світовій економіці.

Постановка завдання. Метою роботи $є$ визначення сутнісних характеристик категорії «контролінг» та розробка методичних рекомендацій щодо підвищення ефективності діяльності підприємства через впровадження системи контролінгу. Для досягнення поставленої мети було визначено такі завдання: 
- аналіз теоретичних підходів до визначення сутності категорії «контролінг» та надання іiї грунтовного трактування з врахуванням сучасних умов господарювання;

- систематизація функцій і завдань контролінгу з розподілом їх за обсягами і межами досягнення;

- надання практичних рекомендацій щодо підвищення ефективності діяльності підприємства через впровадження стратегічного та оперативного контролінгу на виробничих підприємствах України.

Методологія. Теоретико-методологічну основу дослідження становлять наукові праці та методичні розробки провідних вітчизняних і зарубіжних учених в області контролінгу та управлінського обліку. Вирішення наукових завдань здійснювалось з використанням критичного аналізу, наукового узагальнення та систематизації при дослідженні сутності категорії контролінг. Результати дослідження, висновки та рекомендації обгрунтовано шляхом комплексного підходу.

Результати дослідження. Поняття «контролінг» походить від англійського дієслова «to control», яке має різні значення. Відповідно до економічного трактування, це управління та спостереження. Основною причиною появи контролінгу в економічній літературі називають, перш за все, промислове зростання у США наприкінці XIX - початку XX ст., що викликало ускладнення процесів планування та появу нових підходів до економічного управління діяльністю підприємства, спрямованого, в першу чергу, на зниження підприємницьких ризиків та підтримку його поточної платоспроможності. Необхідність зміни принципів управління, у свою чергу, потребувала адекватних та науково обгрунтованих методів виробничого обліку та більш точного фінансового контролю. Вирішення зазначених задач розширило межі облікової роботи порівняно 3 традиційним бухгалтерським обліком господарських операцій, та у 1950 - 1960 рр. широке застосування знаходить методика розрахунку собівартості за прямими витратами (direct-costing), що дозволило застосовувати маржинальний підхід в управлінні поточними витратами з метою оптимізації прибутку.

Подальший розвиток контролінгу був спрямований на розробку технологій управління витратами та методик аналізу бізнес-процесів 3 метою скорочення витрат, пов'язаних із забезпеченням якості продукції та вирішенням екологічних проблем. У 1985 - 1995 pp. у межах контролінгу були розроблені методики управління витратами з метою забезпечення конкурентоспроможності підприємства на базі теорії М. Портера про створення ланцюга вартостей (АВСкалькуляції та АВВ-бюджетування). Після 1995 р. метою контролінгу стає надання керівництву комплексної інформації, необхідної для управління довгостроковим розвитком підприємства (табл. 1). 
Порівняльні характеристики традиційного та сучасного підходів до системи контролінгу [3, с. 254]

\begin{tabular}{|c|c|c|}
\hline $\begin{array}{c}\text { Статті } \\
\text { порівняння }\end{array}$ & «Сучасний підхід» & «Традииійний підхід» \\
\hline Завдання & $\begin{array}{l}\text { - підтримка самоуправління; } \\
\text { - орієнтація на ринок; } \\
\text { - інтеграція стратегічної } \\
\text { оперативної орієнтації, акцент на } \\
\text { прогноз (feedforward). }\end{array}$ & $\begin{array}{l}\text { - стороння керуюча особа, висока } \\
\text { роль контролювання; } \\
\text { - переважно внутрішня орієнтація; } \\
\text { - проблеми підрозділів між етапами } \\
\text { контролінгу, акцент на зворотній } \\
\text { зв'язок (feedback). }\end{array}$ \\
\hline Організа & $\begin{array}{l}\text { - цілісна та провесно-орієнтована } \\
\text { організація; } \\
\text { - починається на ранніх фазах, } \\
\text { прив'язана до ланцюжка вартості; } \\
\text { - центр сервісу (центр прибутку) } \\
\text { передається (частково) на } \\
\text { аутсорсинг. }\end{array}$ & $\begin{array}{l}\text { - жорстка функціонально-дивізійна } \\
\text { та тейлористська орієнтація; } \\
\text { - початок на етапі виробництва, } \\
\text { відсутня орієнтація на ланцюжок } \\
\text { вартості; } \\
\text { - штаб, центр витрат, погляд } \\
\text { виключно з середини підприємства. }\end{array}$ \\
\hline Інструл & $\begin{array}{l}\text { - інтегрування всіх вимірів } \\
\text { інформації; } \\
\text { - орієнтація на вартість компанії; } \\
\text { - активне використання IT- } \\
\text { потенціалу. }\end{array}$ & $\begin{array}{l}\text { - фокусування на рахівництві; } \\
\text { - орієнтація на результат роботи за } \\
\text { період; } \\
\text { - реагування на IT. }\end{array}$ \\
\hline $\begin{array}{l}\text { Розуміння } \\
\text { контролінгу }\end{array}$ & $\begin{array}{l}\text { - новатор, консультант; } \\
\text { - експерт у галузі продуктів, } \\
\text { клієнтів, процесів }\end{array}$ & $\begin{array}{l}\text { - «вартовий пес»; } \\
\text { - експерти у галузі контролінгових } \\
\text { інструментів. }\end{array}$ \\
\hline
\end{tabular}

Проте слід зазначити, що у англомовних джерелах термін «контролінг» практично не використовується. У США, Великій Британії більш поширеним $є$ термін «управлінський облік» (managerial accounting, management accounting), a працівників, на яких покладено виконання функцій ведення управлінського обліку називають контроллерами (controller). У вітчизняній економічній літературі начастую поняття контролінгу та управлінського обліку використовуються як синоніми (табл. 2). Таким чином, аналізуючи наведені трактування категорії «контролінг», можна зазначити, що основне призначення контролінгу - це управління, проте кожен 3 науковців акцентує увагу на окремому аспекті: фінансово-економічний стан підприємства, витрати, прибуток тощо.

Таблиця 2

Основні визначення категорії «контролінг»

\begin{tabular}{|c|c|}
\hline Автор & \multicolumn{1}{|c|}{ 3міст тлумачення } \\
\hline $\begin{array}{c}\text { Манн Р., Майер Е. } \\
\text { [4, с. 8] }\end{array}$ & $\begin{array}{l}\text { Сезуема управління процесом досягнення кінцевих цілей і } \\
\text { відношенні, умовно кажучи, це система управління прибутком } \\
\text { підприємства }\end{array}$ \\
\hline $\begin{array}{c}\text { Фольмут Х. Й. } \\
\text { [7, с. 5] }\end{array}$ & $\begin{array}{l}\text { Цілісна концепція економічного управління підприємством, яка } \\
\text { направлена на виявлення усіх можливостей і ризиків, пов’язаних з }\end{array}$ \\
\hline
\end{tabular}




\begin{tabular}{|c|c|}
\hline & отриманням прибутку в умовах ринку \\
\hline Дайле А. [1, с. 11] & $\begin{array}{l}\text { Процес оволодіння підприємством економічною ситуацією на } \\
\text { ринку }\end{array}$ \\
\hline $\begin{array}{l}\text { Ананькіна О. О., } \\
\text { Данілочкіна Н. Г. } \\
\quad[2, \text { с. } 6]\end{array}$ & $\begin{array}{l}\text { Функціонально відокремлений напрям економічної роботи на } \\
\text { підприємстві, який пов’язаний } 3 \text { реалізацією фінансово- } \\
\text { економічної функції в менеджменті для прийняття оперативних і } \\
\text { стратегічних управлінських рішень }\end{array}$ \\
\hline Хан Д. [8, с. 463] & Автоматизована система управління підприємством \\
\hline $\begin{array}{l}\text { Пушкар М. C., } \\
\text { Пушкар P. М. } \\
\text { [5, c. 12] }\end{array}$ & $\begin{array}{l}\text { Концепція ефективного управління економічним об'єктом } 3 \\
\text { метою забезпечення його сталого і тривалого існування в постійно } \\
\text { змінюваному середовищі }\end{array}$ \\
\hline
\end{tabular}

Вважаємо найбільш грунтовним тлумачення контролінгу як комплексної міжфункціональної концепції управління, метою якої $є$ координація систем планування, контролю та інформаційного забезпечення задля збільшення вартості компанії. Виходячи з такої точки зору, основний інтерес власника компанії - це збільшення її вартості, а витрати, прибуток, фінансово-економічні показники - лише інструменти для вирішення даного завдання.

Відповідно до міжнародної практики, методичними рекомендаціями щодо організації та реалізації контролінгу базовими компонентами останнього на підприємствах виступають:

- система оціночних та порівняльних показників діяльності;

- система обліку та управління витратами;

- система планування операційної, фінансової та інвестиційної діяльності, бюджетування;

- система управлінської звітності.

Виходячи 3 сучасної концепції контролінгу, виділяють наступні специфічні функції контролінгу [9, с. 170]:

- попереднє планування цілей та засобів;

- розробка варіантів вирішення, зокрема, аналіз альтернатив, передумов та наслідків управлінських рішень;

- облік та інтерпретація даних контролю (наприклад, у формі відхилень від бюджету, сигналів раннього повідомлення тощо);

- впровадження результатів, отриманих в процесі контролю, у наступний процес планування (наприклад, формі пропозицій щодо корегування напрямку розвитку підприємства).

Система контролінгу повинна бути адаптована до специфічних факторів підприємства, зокрема: оточуюче середовище (вимоги законодавства, політика, ринки постачання та збуту тощо) та внутрішне середовище (виробнича програма, технологія виробництва продукту, розмір та організація підприємства, стиль керівництва, який виражається у задачах та інструментарії контролера тощо). Також слід відзначити, що при організації 
контролінгу задачі, пов'язані з обліком, формулюються залежно від того, яка концепція контролінгу (німецька чи американська) покладені в основу. За американською концепцією до контролінгу відносяться також задачі зовнішнього (фінансового) обліку. В центрі німецької концепції контролінгу стоїть внутрішній облік у різних формах: плановий, документальний, контрольний; фінансовий облік у сферу контролінгу не входить. Як свідчить практика діяльності сучасних підприємств [6], функції контролінгу виділяються в окремий підрозділ, оскільки не має сенсу дублювати функції звичайної бухгалтерії підприємства, а 3 іншого боку, ускладнювати та загромаджувати процес управління підприємством.

У межах контролінгу формуються не тільки фінансові показники, але й показники фактичної та прогнозної оцінки економічних результатів діяльності підприємства в цілому та всіх його структур. На основі такої інформації можуть прийматися управлінські рішення стосовно найширшого кола проблем та напрямків: ціноутворення, нарощування чи скорочення виробничих потужностей, удосконалення процесів управління витратами, контроль виконання планів тощо. Завдання та відповідальність контролера сформульовані у місії контролера, розробленої Міжнародною групою контролінгу (International Group of Controlling) у 2002 р., відповідно до якої контроллери:

- організують та супроводжують процес постановки цілей, планування та управління, несучи тим самим сумісну відповідальність за досягнення цілей;

- забезпечують прозорість результатів, фінансів, процесів та стратегій, сприяючи досягненню більш високої ефективності;

- координують підцілі та підплани у межах єдиного цілого та організовують систему внутрішньо фірмової звітності;

- будують процес постановки цілей, планування та управління для орієнтації співробітників, приймаючих рішення, на цілі компанії;

- забезпечують збір необхідних даних та інформації;

- створюють та обслуговують контролінгові системи [3, с. 19].

У зв'язку з багатоманітністю внутрішніх та зовнішніх факторів, які впливають на господарську діяльність підприємства, не може бути спільних та прийнятних для всіх положень про «правильну» організацію контролінгу. Система контролінгу повинна бути адаптована до специфічних, контекстних зовнішніх та внутрішніх факторів конкретного підприємства. Виділяють системи контролінгу, які відображають галузеву специфіку підприємств промисловий, банківський контролінг, контролінг у страхових компаніях та у торгівлі. Залежно від складу даних та формату управлінської звітності доцільно виділяти наступні види контролінгу: контролінг персоналу, контролінг виробництва, контролінг логістики, контролінг інформації, 
контролінг витрат тощо. Один 3 можливих варіантів структури контролінгу у торговельній компанії наведений у таблиці 3.

Таблиця 3

Вагомі елементи системи контролінгу у торговельній компанії [3, с. 29]

\begin{tabular}{|l|l|}
\hline $\begin{array}{l}\text { Загальний } \\
\text { контролінг }\end{array}$ & $\begin{array}{l}\text { - фінансовий контролінг, організаційне та стратегічне планування, } \\
\text { інвестиційний контролінг, управління філіалами, розвиток } \\
\text { підприємств різних типів, загальне управління клієнтами }\end{array}$ \\
\hline $\begin{array}{l}\text { Контролінг } \\
\text { персоналу }\end{array}$ & $\begin{array}{l}\text { - гнучке планування персоналу та вимірювання результативності через } \\
\text { сканування, «кваліфікаційний контролінг» }\end{array}$ \\
\hline $\begin{array}{l}\text { Контролінг } \\
\text { асортименту }\end{array}$ & $\begin{array}{l}\text { - планування асортименту (повторне включення чи виключення } \\
\text { окремих видів товарів до продуктового портфелю, загальне управління } \\
\text { товарними групами), регулювання та контроль асортименту }\end{array}$ \\
\hline $\begin{array}{l}\text { Контролінг } \\
\text { використання } \\
\text { площз }\end{array}$ & $\begin{array}{l}\text { - управління використанням площ на основі сканування аналітичних } \\
\text { даних про ефективність використання площ, системи управління площ }\end{array}$ \\
\hline $\begin{array}{l}\text { Контролінг } \\
\text { складського } \\
\text { господарства }\end{array}$ & $\begin{array}{l}\text { - система замовлень, зовнішня та внутрішня логістичні системи, } \\
\text { приймання та координація роботи складу, відвантаження товару }\end{array}$ \\
\hline
\end{tabular}

Для побудови системи інформаційного забезпечення необхідно визначити потреби в інформації, зібрати й підготувати інформацію (через систему обліку) та передати іiі (через систему звітності). Система інформаційного забезпечення (системи обліку та звітності), система планування (стратегічні, тактичні та оперативні плани) та контролю не можуть бути побудовані незалежно один від одного.

Цільове планування має включати визначення вищих матеріальних, вартісних та соціальних цілей, а також формування продуктових програм та інших цільових комплексів. Стратегічне планування визначає ядром довгострокового планування продуктової програми та потенціалу. Його можна також назвати плануванням стратегій галузей бізнесу (бізнес одиниць), інтегрованим 3 плануванням стратегій функціональних та регіональних підрозділів. Окрім того, предметом стратегічного планування $\epsilon$ організаційна та правова структура, система управління підприємством (планування розташування керівного персоналу, системи стимулювання менеджерів та інформаційної системи підтримки прийняття управлінських рішень). Оперативне планування слід організувати на основі цільового та стратегічного планів. На основі заданого потенціалу в розрізі окремих підрозділів підприємства розробляється коротко- та середньострокова продуктова програма, що максимізує суму покриття. Загальнофірмове фінансово-економічне планування $є$ грошовим вираженням всіх окремих планів підприємства та включає розрахункове та балансове планування 
результату, а також фінансове планування. На даному етапі планують та контролюють всі істотні монетарні показники вартісно-орієнтованого управління. Контроль витрат, рівень яких формується підприємством виходячи з цих планів, здійснюється у межах стратегічного та оперативного контролінгу.

Метою стратегічного контролінгу має бути забезпечення ефективного функціонування та виживання підприємства на довгострокову перспективу. Основний принцип управління при цьому - орієнтація на створення економічної вартості у середньостроковій та довгостроковій перспективі в ході безперервного розвитку підприємства при припустимому рівні ділових ризиків. Завданням стратегічного планування (бізнес-планування) на рівні підприємства в цілому $\epsilon$ позиціонування окремих стратегічних зон господарювання (бізнес-одиниць) у загальному бізнес-портфелі підприємства (табл. 4). У такому бізнес-портфелі зазначається ринкова, технологічна та екологічна привабливість кожної бізнес-одиниці, його відносні конкурентні переваги та інші ключові параметри. Ринкова привабливість кожної бізнесодиниці визначається часткою ринку, яку займає дана бізнес-одиниця. Технологічна привабливість поля бізнесу оцінюється 3 позицій ефективності технології продукту та технології його виробництва. Екологічна привабливість стратегічного продукту підприємства розглядається 3 позицій ступеня забруднення навколишнього середовища при виробництві продукту, його використанні та утилізації.

Загальнофірмовий бізнес-портфель повинен бути цілком збалансованим 3 точки зору фінансового результату, поточних грошових потоків та ризику. Даній меті служить оперативний контролінг, під яким слід розуміти контрольно-інформаційну систему управління, спрямовану на забезпечення поточних цілей підприємства (перш за все, цілей прибутковості, рентабельності та платоспроможності) на основі прийняття своєчасних рішень щодо оптимізації співвідношення «витрати - прибуток». Система оперативного контролінгу включає: завдання, організацію (контролінг підрозділів) та інструменти контролінгу: системи оперативної та поточної звітності, системи оперативної реєстрації (наприклад, фінансова бухгалтерія), аналіз чутливості бізнесу (CVP-аналіз), розрахунок сум покриття, бюджетування, дисперсійний аналіз виконання плану витрат та прибутку, оперативна діагностика діяльності підприємства тощо.

Таблиця 4

Основні завдання стратегічного та оперативного контролінгу 


\begin{tabular}{|c|c|}
\hline $\begin{array}{l}\text { 1. Забезпечення місії підприємст } \\
\text { встановлення цілей діяльності; } \\
\text { 2. Розробка стратегії розвитку підпри } \\
\text { на основі певних припущень } \\
\text { поточний стан та майбутні } \\
\text { внутрішнього та зовнішнього серед } \\
\text { планування та контроль всіх } \\
\text { спрямованих на довгостроковий ро }\end{array}$ & 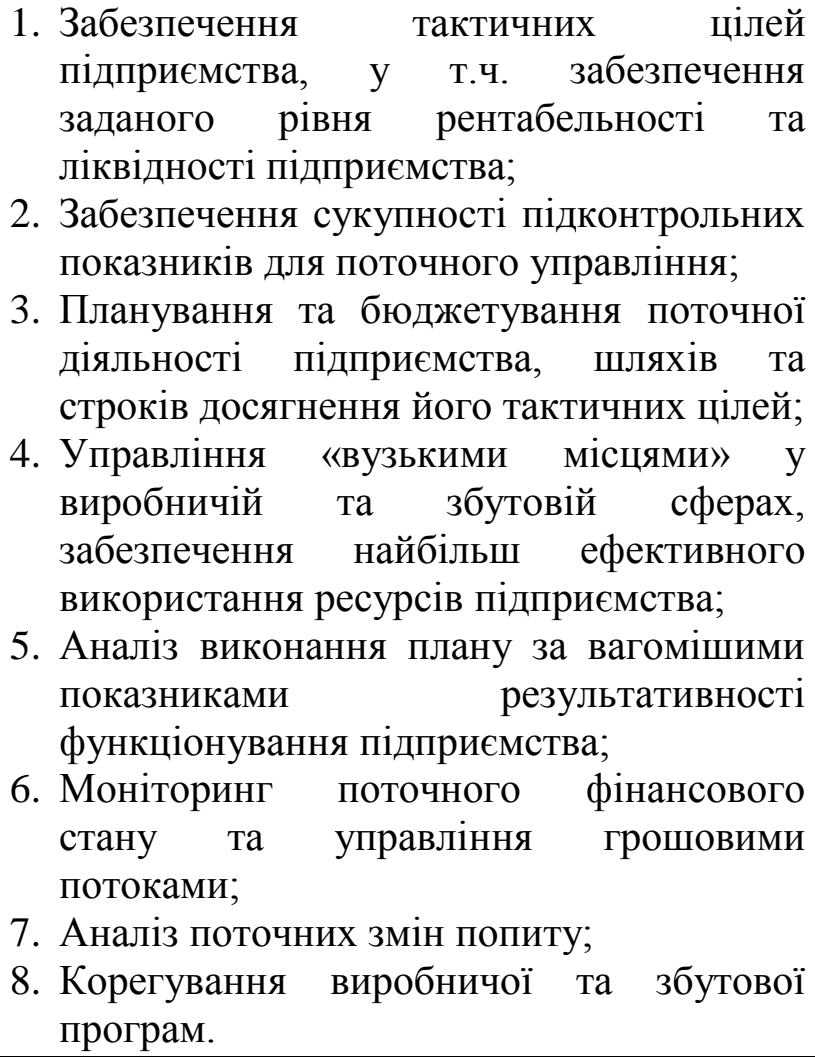 \\
\hline
\end{tabular}

Будь-яке підприємство можна розглядати як систему керуючих постулатів, яка визначається соціальними та економічними цілями. До економічних цілей відносять виробничі, фінансові та результативні цілі. Виробничі та фінансові цілі відображають реальну сферу господарських операцій підприємства та відносяться до матеріальних економічних цілей, результативні цілі формальні, відображають обсяг економічної ефективності в процесі реалізації матеріальних економічних цілей [9, с. 77-78]. Водночас, 3 точки зору основних контрагентів підприємства - інвесторів, працівників, споживачів, постачальників, держави - головною метою підприємства $\epsilon$ його збереження та сталий розвиток. Проте у сучасних економічних умовах, що притаманні ринковій економіці, наявність прибутку не гарантує підприємству виживаність не лише у довгостроковій перспективі, але й у короткостроковій. У конкурентних умовах базою оцінки підприємства виступають чисті грошові потоки, які розраховуються як різниця між усіма надходженнями та виплатами грошових коштів, отриманих в результаті господарських операцій. Довгострокова ефективність функціонування підприємства оцінюється з позиції оптимізації дисконтованого фінансового результату. У короткостроковому періоді необхідною умовою його існування $є$ підтримка постійної ліквідності. Фінансовий результат виражається через взаємозв'язок категорій прибутку, доданої вартості та грошових потоків. Таким чином, завдання контролінгу в сучасних умовах господарювання полягає в оптимізації фінансового 
результату через максимізацію прибутку та цінності капіталу при гарантованій ліквідності. Цінність капіталу визначається ринковою вартістю чистих активів підприємства. Під ліквідністю розуміють здатність підприємства у будь-який час без жодних обмежень здійснювати всі обов'язкові платежі, що припадають на даний момент часу. Водночас, за допомогою контролінгу монетарна ціль координується 3 досягненням соціальних і ринкових цілей та ресурсами, необхідними для реалізації даного заходу, що особливо важливо в умовах макроекономічної нестабільності в країні.

Висновки. За результатами дослідження визначено, що історично склалися дві концепції контролінгу: німецька, заснована на використанні даних внутрішнього обліку, та американська, що розширює межі управління 3 врахуванням даних фінансового обліку. На даний час існують різні підходи до визначення сутності контролінгу, орієнтовані на встановлення певних цілей менеджерів вищої ланки.

Науковою новизною $є$ запропоноване визначення контролінгу як комплексної міжфункціональної концепції управління, метою якої є координація систем планування, контролю та інформаційного забезпечення задля збільшення вартості компанії, яке на відміну від існуючих підходів, враховує глобальні цілі власника - примноження його капіталу.

3 метою забезпечення сталого розвитку підприємства в умовах макроекономічної нестабільності в країні запропоновано виділяти стратегічний та оперативний контролінг. Стратегічний контролінг виконує функцію реалізації стратегії - від стратегічного планування до стратегічного управління. Основні завдання при цьому - координація стратегічного планування та контролю, а також надання інформації, вагомої для прийняття стратегічних рішень. Оперативний контролінг сприяє поточному плануванню, при цьому основна увага має приділятися короткостроковим трендам, інформація про які виражена у вигляді доходів та витрат. Фокус уваги оперативного контролінгу зосереджений на внутрішньому середовищі підприємства (не на оточенні) та сконцентрований на поточній його господарській діяльності. Вважаємо, що інтегрована система контролінгу, включаючи завдання, організацію та інструменти, допомагає правильно та своєчасно оцінювати ситуацію на підприємстві й планувати дії щодо підвищення ефективності його роботи.

Подальшого дослідження потребує проблема адаптації та впровадження концепції контролінгу з врахуванням галузевих особливостей промислових підприємств Україні на основі стандартів СС.

\section{Література:}

1. Дайле А. Практика контроллинга: Пер. с нем. / Под ред. и с предисл. М. Л. Лукашевича, Е. Н. Тихоненковой. - М.: Финансы и статистика, 2001. - 342 с. 
2. Контроллинг как инструмент управления предприятием / Е. А. Ананькина, С. В. Данилочкин, Н. Г. Данилочкина и др.; Под ред. Н. Г. Данилочкиной. - М.: Аудит, ЮНИТИ, 2001. - 540 с.

3. Концепция контроллинга: Управленческий учет. Система отчетности. Бюджетирование / Horvart \& Partners; Пер. с нем. - 3-е изд. - М.: Альпина Бизнес Букс, 2008. - 269 с.

4. Манн Р. Контроллинг для начинающих / Р. Манн, Е. Майер. - М.: Финансы и статистика, 1995. - 469 с.

5. Пушкар М. С. Контролінг - інформаційна підсистема стратегічного менеджменту: Монографія / М. С. Пушкар, Р. М. Пушкар. - Тернопіль: Карт-бланш, 2004. - 340 с.

6. Семенов А. Стратегическая модель развития на 3-5 лет позволяет вырваться из привычных рамок годового бюджета / А. Семенов // Материалы третьей ежегодной конференции «Корпоративное бюджетирование», Москва, 24-26 сентября 2014 г. [Электронный pecypc]. russia.ru/stati/index.php?article $=9465$.

7. Фольмут Х. Й. Инструменты контроллинга от А до Я: Пер. с нем. / Под ред. и с предисл. М. Л. Лукашевича и Е. Н. Тихоненковой. - М.: Финансы и статистика, 2001. 203 с.

8. Хан Д. Планирование и контроль: концепция контроллинга: Пер.с нем. / Под ред. и с предисл. А. А. Турчака, Л. Г. Головача, М. Л. Лукашевича. - М.: «Финансы и статистика», 1997. - 758 с.

9. Хорнгрен Ч. Управленческий учет, изд. 10-е / Ч. Хорнгрен, Дж. Фостер, Ш. Датар; Пер. с англ. - Спб.: Питер, 2005. - 1008 с.: ил. 